\title{
12 Mart 1971 Askerî Müdahalesi Sonrası Ara Rejim ve Türkiye Siyasetine Etkileri (1971-1974)*
}

\author{
DOI: $10.26466 /$ opus. 407560 \\ *
}

\author{
$\underline{\text { Barıș Ertem }^{*}}$ \\ * Öğr.Gör. Dr. İstanbul Teknik Üniversitesi İstanbul / Türkiye \\ E-Posta: ertbar@gmail.com \\ ORCID: 0000-0001-5091-2807
}

\section{Öz}

12 Mart 1971 tarihinde dönemin Başbakanı Süleyman Demirel'e askerler tarafından gönderilen muhtıra, Türkiye Cumhuriyeti tarihinde askerlerin sivil ve seçilmiş siyasi iktidara yönelik doğrudan ikinci müdahalesi olmuştur. Bu müdahaleyle iktidardaki Başbakan Süleyman Demirel ve tek başına kurmuş olduğu Adalet Partisi Hükümeti iktidardan uzaklaştırılmıştır. Muhtıranın ve askerin tekrar siyasete müdahalesinin etkileri, yaklaşık 3 buçuk yıl kadar sürmüş, bu süre içerisinde, 1972 yılında CHP'nin 34 yillık genel başkanı ve Türkiye Cumhuriyeti'nin ikinci Cumhurbaşkan olan İsmet Inönü, partide düzenlenen olağanüstü kurultayı kaybederek yerini partinin Zonguldak Milletvekili ve eski genel sekreteri Bülent Ecevit'e bırakmıştır. Muhtıranın etkileri 1973 yılında yapılan Cumhurbaşkanlı̆̆ seçimi sürecine de yansımıştır. Askerler ve sivil siyasetçiler, Cumhurbaşkanı adayı konusunda karşı karşıya gelmiştir. İki sivil siyasi lider Süleyman Demirel ve Bülent Ecevit'in, askerlerin gösterdiği Cumhurbaşkanı adayı Orgeneral Faruk Gürler'e karşı işbirliği yaparak ortak aday belirlemeleri sonucu, Cumhurbaşkanliğı seçimlerinde sivil siyasetçilerin dediği olmuştur. Cumhurbaşkanlığı seçimlerinde yaşanan bu krizin de aşılmasından sonra, 1973 yılının Ekim ayında genel seçimlerin yapılmasına karar verilmiştir. Belirlendiği tarihte ve yüksek bir katılımla gerçekleşen bu genel seçimleri, Cumhuriyet Halk Partisi kazanmıştır. Genel Başkan Ecevit, kendisinden sonra en yüksek oyu alan Demirel'le bir koalisyon hükümeti kurmak istemediğinden, Milli Selamet Partisi Genel Başkanı Necmettin Erbakan'la görüşmelere başlamıştır. Bu görüşmeler sonucunda, Bülent Ecevit, 1974 yılının Şubat ayında Necmettin Erbakan ile ortak bir koalisyon konusunda anlaşmıştır. CHP-MSP Hükümeti'nin kurulmasıyla, yaklaşık 3 buçuk yıl süren 12 Mart 1971 ara rejim süreci sona ermiştir.

Anahtar Kelimeler: 12 Mart 1971 Muhtırasl, Adalet Partisi (AP), Cumhuriyet Halk Partisi (CHP

\footnotetext{
*Bu çalışmadan, 2-4 Şubat 2018 tarihinde düzenlenen Uluslararası Multidisipliner Akademik Çalışmalar Sempozyumu'nda sunulan "Türk Siyasetinde Asker-Sivil ilişkileri (1971-1980)" başlıklı bildiride yararlanılmıştır ve ileride yayımlanacak olan sempozyum bildiri kitabında da yer alacaktır.
}

OPUS (c) Uluslararası Toplum Araştırmaları Dergisi-International Journal of Society Researches ISSN:2528-9527 E-ISSN : 2528-9535

http://opusjournal.net 


\title{
Interim Regime After March 12, 1971 Military Inter- vention and the Effects to the Turkish Politics (1971- 1974)
}

\begin{abstract}
On March 12, 1971, Prime Minister of Republic of Turkey, Süleyman Demirel was given a memorandum by the soldiers. This memorandum was soldiers' second direct intervention to the civilian and selected political power in the history of the Republic of Turkey. As a result of this military intervention, ruling Prime Minister Süleyman Demirel and his Justice Party Government (AP) fell from power. Impact of the military intervention on Turkish politics was about three and a half years. In this process, İsmet Inönü, the 34-year-old Chairman of the Republican People's Party $(\mathrm{CHP})$ and second president of the Republic of Turkey, lost his place in the party. Former general secretary, Bülent Ecevit, became the new Chairman of the CHP. The memorandum also affected the presidential elections held in year of 1973. The soldiers and civilian politicians have faced about presidential candidate. The candidate, who by Süleyman Demirel and Bülent Ecevit, elected as president. The general elections were held in October, 1973. Republican People's Party (CHP), led by Bülent Ecevit, has won the elections. But he had to set up a coalition government. Ecevit did not want to set up a coalition government with Süleyman Demirel. Ecevit has formed a coalition government with Necmettin Erbakan-led National Salvation Party (MSP). As the result of formation of this civilian coalition government, the interim regime has ended.
\end{abstract}

Keywords: March 12, 1971 Military Memorandum, Justice Party (AP), Republican People's Party (CHP)

OPUS (c) Uluslararası Toplum Araştırmaları Dergisi-International Journal of Society Researches ISSN:2528-9527 E-ISSN : 2528-9535

http://opusjournal.net 


\section{Giriş}

\section{Askerî Müdahalesine Genel Bir Bakıș}

1970'lere yaklaşılırken, Başbakan Süleyman Demirel'in başında bulunduğu Adalet Partisi (AP) Hükümeti, Johnson Mektubu sonucu toplumda yükselen ABD-karşıtı tepkiler, TIIP'in Meclise girmesi ve DİSK, Dev-Sol gibi yapıların güçlenmesi gibi nedenlerle artan sol faaliyetlerden ordunun duyduğu rahatsızlık, DP'lilerin siyasî haklarının iadesine ordu içerisinden gelen tepkiler, sokaklarda ve üniversitelerde şiddet olaylarının görülmeye başlaması gibi nedenlerle, iç politikada büyük baskı altındadir.

Demirel Hükümeti, içeride bu sorunlarla karşı karşıya iken dış politikada da büyük sorunlar yaşamaktadır. Ülkesinde artan uyuşturucu kullanımından Türkiye'yi sorumlu tutan ABD Başkanı Nixon, afyon üretimini durdurması için Demirel Hükümeti'ne baskı yapmaktadır. Afyon ekiminden geçimini sağlayan yüzbinlerce kişinin tepkisinden çekinen Demirel'in üretimi tamamen durdurmaması, ABD'nin büyük tepki ve baskısına neden olmuştur. ${ }^{1}$

1971 yılına girildiğinde, Demirel Hükümeti, bu iç ve diş sorunlar nedeniyle hareket edemez durumdadır ve ordunun komuta kademesinde de müdahale fikri ağırlık kazanmıştır. Yalnızca Genelkurmay Başkanı Memduh Tağmaç, müdahale fikrine soğuk bakmaktadır. 1960'ların başlarında çıkarttıkları Yön Dergisi'nden sonra, bir süredir çıkarttıkları Devrim Dergisi'ndeki yazılarıyla da ordunun yönetime müdahale etmesi gerektiği fikrini savunan Doğan Avcıoğlu, İlhan Selçuk gibi bazı sol görüşlü aydınlardan da etkilenen komutanlar, 9 Mart 1971 tarihinde darbe kararını kesinleştirmek amacıyla toplanmışlardır. Ancak, Kara Kuvvetleri Komutanı Faruk Gürler'in son anda vazgeçmesi nedeniyle darbe gerçekleştirilememiştir. Faruk Gürler, Genelkurmay Başkanı Memduh Tağmaç'ın da darbeyi desteklemesi gerektiğini düşünmektedir. Sonun-

\footnotetext{
${ }^{1}$ Konuyla ilgili ayrıntılı bilgi için: Barış Ertem, "Türk Siyasetinde Asker-Sivil Ilişkileri (1960-1971)", Dicle Üniversitesi Sosyal Bilimler Enstitüsü Dergisi, Cilt 8, Sayı 16, 2016, s.132-149; Barış Ertem, "Türkiye Cumhuriyeti Tarihinde Asker-Sivil ilişkileri (1923-2000), Modern Türkiye Tarihi, (ed.Ali Satan, Süleyman Beyoğlu), İstanbul: Marmara Üniversitesi Yayınları, 2014, s.423-440
} 
da, hem Memduh Tağmaç hem de Cumhurbaşkanı Cevdet Sunay darbeye ikna edilmiştir.

Sonunda, ordunun komuta kademesi, 27 Mayıs 1960'dan yaklaşık 11 yıl sonra, sivil siyasete yeniden müdahale etmeye karar vermiştir. 12 Mart 1971 günü, saat 13.00'de, Genelkurmay Başkanı Memduh Tağmaç ve kuvvet komutanlarının imzasını taşıyan muhtıra Türkiye Radyolarında okunmuş ve Süleyman Demirel Hükümeti istifaya davet edilmiştir. Cumhurbaşkanı Cevdet Sunay'a, Başbakan Demirel'e, Millet Meclisi'ne ve Cumhuriyet Senatosu'na da yazılı olarak da gönderilen 3 maddeli muhtıra metnine göre, Demirel askerlerin taleplerini yerine getirip istifa etmez ve yerine askerlerin onaylayacağı bir hükümet kurulmazsa, ordu idareyi doğrudan üzerine alacaktır. Muhtıranın tam metni şöyledir:

1. Parlamento ve hükümet, süregelen tutum, görüş ve icraatı ile yurdumuzu anarşi, kardeş kavgası, sosyal ve ekonomik huzursuzluklar içine sokmuş, Atatürk'ün bize hedef verdiği çağdaş uygarlık seviyesine ulaşmak ümidini kamuoyunda yitirmiş ve anayasanın öngördügü reformları tahakkuk ettirememiş olup, Türkiye Cumhuriyeti'nin geleceği ağır bir tehlike içine düşürülmüştür.

2. Türk Milletinin ve sinesinden çıkan Silahlı Kuvvetleri'nin bu vahim ortam hakkında duyduğu üzüntü ve ümitsizliği giderecek çevrelerin, partiler üstü bir anlayışla meclislerimizce değerlendirilecek, mevcut anarşik durumu giderecek ve anayasanın öngördügü reformları Atatürkçü bir görüşle ele alacak ve inkılâp kanunlarını uygulayacak kuvvetli ve inandırıcı bir hükümetin demokratik kurallar içinde teşkili zaruri görülmektedir.

3. Bu husus süratle tahakkuk ettirilmediği takdirde, Türk Silahlı Kuvvetleri, kanunların kendisine vermiş olduğu, Türkiye Cumhuriyeti'ni korumak ve kollamak görevini yerine getirerek idareyi doğrudan doğruya üzerine almaya kararlıdır.

Bilgilerinize. (Milliyet, 13 Mart 1971; Cumhuriyet 13 Mart 1971)

Muhtıranın bildirilmesinden hemen sonra, Bakanlar Kurulu olağanüstü toplanmış ve alınacak karar görüşülmüştür. Toplantı sonucunda hükümetin istifasına karar verilmiş ve Başbakan Süleyman Demirel, 
muhtıradan yaklaşık 4 saat sonra, saat 17.00'de Cumhurbaşkanı Cevdet Sunay'a gönderdiği şu mektupla görevinden istifa etmiştir:

“Cumhurbaşkanlığı Yüce Katına,

Genelkurmay Başkan ve kuvvet komutanları tarafindan zatı devletinize,Cumhuriyet Senatosu Başkanlığına ve Millet Meclisi Başkanlığına tevdi edilip bugün saat 13.00'te Türkiye Radyolarından Türk Kamuoyuna duyurulan muhtırayla anayasa ve hukuk devleti anlayışını bağdaştırmak mümkün değildir. Bu durum muvacehesinde hükümetin istifasın saygryla arz ederim.

Süleyman Demirel, Başbakan." (Cumhuriyet, 13 Mart 1971)

\section{Muhtıra Sonrası Ara Rejimin (1971-1974) Türkiye Siyasetine Etkileri}

\section{12 Mart 1971 Askerî Muhtırasının CHP Üzerindeki Etkileri ve Par- tide Lider Değişimi}

12 Martçılar, Demirel Hükümeti'nin istifasının ardından, özellikle kendi aralarındaki görüş farklılıkları nedeniyle, selefleri 27 Mayısçılardan fark11 olarak Meclis'i ve siyasi partileri kapatmamışlar, Meclis aritmetiğini değiştirmemişlerdir. Buna karşılık Meclis'teki partilerin hükümet kurmalarına izin vermemişler, kendilerinin seçtikleri kişilerden kurulmuş "partiler üstü" hükümetler aracıllğıyla ülkeyi yaklaşık üç yıl yönetmişlerdir. Bu ara rejim döneminde sırasıyla görev yapan hükümetler şöyledir:

33. Hükümet - Nihat Erim (26 Mart 1971-11 Aralık1971)

34. Hükümet - Nihat Erim (11 Aralık 1971-22 Mayıs 1972)

35. Hükümet - Ferit Melen (22 Mayıs 1972-15 Nisan 1973)

36. Hükümet - Mehmet Naim Talu (15 Nisan 1973-26 Ocak 1974)

Muhtıradan hemen sonra özellikle sola karşı büyük bir baskı başlamış, aralarında Devrim Dergisi'nin bazı yazarlarının da bulunduğu birçok sol görüşlü aydın ve vatandaş tutuklanmıştır. TïP kapatılmış, sol görüşlü dernekler dağıtılmıştır. Kapatılan bu sol yapıların pek çok üyesi, özellikle Genel Sekreter Bülent Ecevit'in teşvikiyle CHP'ye üye ya da delege olarak katılmışlardır.

12 Mart askerî müdahalesi, iktidardan uzaklaştırılan AP kadar, anamuhalefet partisi konumundaki CHP üzerinde de etkili olmuştur. CHP yönetimi, partinin muhtıraya yönelik tavrı üzerinden görüş ayrılığı ya- 
şamış, partide tartışmalar başlamıştır. CHP Genel Başkanı İsmet İnönü, muhtıraya tepki göstermeyen, hatta kismen destekleyen bir tutumu tercih etmiştir. Öyle ki, muhtıradan bir gün sonra basına yaptığı açıklamada, "Demokratik bir istifa var. Demokratik bir mekanizma normal olarak işliyor. Bakalım göreceğiz" diyerek yaşanan sürecin "demokratik ve normal" olduğunu iddia etmiştir. (Cumhuriyet, 13 Mart 1971) Dönemin Cumhurbaşkanı Orgeneral Cevdet Sunay'ın davetiyle, 12 Martçıların kurduracağ1 hükümete bakan vermeyi de kabul eden İnönü'nün, müdahaleyle ilgili düşünceleri özetle şöyledir:

“(...) Memleket ve devlet, hükümetsiz, anarşi içinde başıboş bırakılırsa, onun siyasetçileri hiçbir sorumluluk taşımaksızın selâmete götürmekle mükellef oldukları milletin ve devletin kaderini meçhullere kaptırmış olurlar. Böyle bir sorumluluğu üzerimize almadı. Cumhurbaşkanının davetine olumlu cevap vermek fikrindeyiz. Partiler üstü bir hükümet teşekkül etsin, asayiş korunsun, reformlar yapılsın, sonunda mümkün olan en kısa zamanda seçimlere gidilsin. Bu suretle demokratik rejim kısa zamanda avdet etmiş olur. Takip ettiğimiz politika budur." (Mirkemaloğlu, 1975: 68)

İnönü'nün 12 Mart müdahalesine yönelik bu politikasına CHP içerisinden en belirgin tepki ise Genel Sekreter Bülent Ecevit'ten gelmiştir. Ecevit, İnönü'nün darbeden sonra kurulacak hükümete bakan vereceğini açılaması üzerine partideki genel sekreterlik görevinden istifa etmiştir. Açıklamasında, "İnönü ile karşı karşıya gelerek partiyi yönetemem" diyen Ecevit'e, yürütme kurulunun 15 üyesi de istifalarıla destek vermiştir. (Hürriyet, 22 Mart 1971)

Ecevit, istifasının ardından, kendisini destekleyen partililerle birlikte, İnönü'ye yeni hükümete katılma yetkisinin verilmesine de karşı çıkmıştır. CHP'nin hükümete bakan vermesi konusunda Genel Başkan İnönü'ye tam yetki sağlayan önergeye, Ecevit ile birlikte $50 \mathrm{CHP}$ 'li milletvekili ve senatör "hayır" oyu vermiştir. Ecevit, bu oylamayı 76'ya karşı 50 oyla kaybetmiş olmasına karşın, $\mathrm{CHP}^{\prime}$ de artık yeni bir güç merkezi olduğunu göstermiştir. (Tercüman, 22 Mart 1971)

Genel Başkan İsmet İnönü ile eski Genel Sekreter Bülent Ecevit arasındaki bu ayrışma zamanla bölünmeye dönüşmüş, il kongrelerinde 
"Ecevitçiler ve Paşacılar" karşı karşıya gelmeye başlamıştır. Bölünmenin boyutları, İnönü'nün yaklaşık 1 yıl kadar sonra, 5 Şubat 1972 tarihinde CHP Ortak Grup Toplantısında yaptığı konuşmasındaki sertlikten anlaşılabilmektedir. İnönü, grup toplantısındaki konuşmasında, Ecevit'in son 1 yıl içerisindeki tavrını açıkça sert bir şekilde eleştirmiş ve "memleket için meçhul" olarak değerlendirmiştir:

“(...) 12 Mart'tan sonra, hükümet teşkili çalışmaları sırasında, büyük devlet ve millet bunalımına çare bulma konusunda Genel Sekreter, o sahada başlica sorumlu TBMM Grubu ve Genel Başkan ile ters düştü̈̆̈̈nü ilân etmiştir. Bunun ve yalnı bunun sonucu olarak da bana istifasını göndermiştir. $O$ andan itibaren eski Genel Sekreter, inanılmaz bir ısrar ile sanki herkesin gözü önünde cereyan etmiş bu görüş ayrilığından değil de, Ortanın Solu anlayışı farkından ve ya halka dayanma konusunda bir ihtilâf varmış da ondan ayrılmış gibi kongre sonuçlarmı tefsir etmekte ve ya ettirmektedir.

(...) Şimdi, hükümet teşkili zamanındaki anarşizm hâkimiyeti deorini göz önüne getiriniz. Memleket, ne olursa olsun, emniyete kavuşmak için tamamı ile bunalmış bir haldeydi. O zaman, süratle hükümet teşkilini imkânsız kilacak bir davranışa, Genel Sekreterin aklına uyarak girseydik, memlekette anarşi daha ne kadar tahribat yapabilirdi, tasavvur edebilir misiniz?

(...) Bugünkü Parti Meclisi, başka türlü bir Merkez Yönetim Kurulu seçemez. Çünkü kurultay, Genel Başkanla herhangi bir ihtilâfı olmadığımı söyleyen Genel Sekreter rahat çalışabilsin diye ve benim bunu anlatmam sonucu böyle bir Parti Meclisini onun yanma vermiştir. Eski Genel Sekreter, esas noktalarda artık başka görüşte olduğunu söyleyince, Parti Meclisinde bulunan çoğunluk, onun yeni ve bilinmeyen politikasının icra vasıtası haline gelmiştir. Memleket için meçhul, parti için meçhul." (Turan, 2004: 279-284).

İnönü ile Ecevit arasında, dolayısıyla $\mathrm{CHP}^{\prime}$ de artık iyice belirginleşen bu bölünme, sonunda partiyi olağanüstü kurultaya taşımıştır. $\mathrm{CHP}^{\prime} \mathrm{de}$ İnönü'ye en yakın ve etkili isimlerden Kemal Satır, İnönü'nün talimatıyla, Ecevit Grubunu partiden tasfiye etmek amaciyla olağanüstü kurultay için imza toplamaya başlamıştır. Satır'ın yeterli imza sayısını aşan 368 imzalı dilekçesini 16 Nisan 1972 tarihinde Genel Başkan İsmet İnönü'ye sunmasıyla, kurultay süreci başlamıştır (Cumhuriyet, 17 Nisan 1972). 
İnönü, dilekçeyi kabul ettikten sonra konuyu Parti Meclisi'ne taşımış ve Kemal Satır'ı destekleyen, Ecevit'e muhalif tavrını ortaya koyduğu bir konuşma yapmıştır. Ecevitçilerin kurultay tarihi ve delegelerle ilgili bazı itirazlarına karşın, İnönü'nün etkisiyle, olağanüstü kurultay tarihi 5 Mayıs 1972 olarak belirlenmiştir. İnönü, toplantıyı kapatırken şunları söylemiştir:

“Onlar (İnönü'yü destekleyen üyeler) bana bir tarih bildirdiler, 15 Mayıs olur dediler. Siz (Ecevitçi üyeler) 29 Nisan diyorsunuz. Ben bir formül söylüyorum, 5 Mayıs diyorum. Bunu şimdi gidip ilân edeceğim. Toplantımız bitmiştir." (Turan, 2004: 304).

Toplantının ardından, Genel Başkan İnönü'nün olağanüstü kurultayla ilgili bildirisi yayımlanmıştır:

"Adana Milletvekili Sayın Kemal Satır'ın öncülük ettiğgi senatör ve milletvekilleri, illerden toplananlarla birlikte 363 imza ile olağanüstü kurultayın toplanması için 16 Nisan tarihinde bana müracaat etmişlerdir. 18 Nisanda Parti Meclisine bilgi olarak bunu söylediğim vakit, Parti Meclisi, kendisine karşı yapılan şikâyetleri cevaplamaya çalışmakla birlikte, kendilerinin de olağanüstü bir kurultay toplanmasını isteme kararı alacaklarmı bildirdiler. Illk müracaat, tüzüğ̈̈müzün kendilerine verdiği hakkı kullandıklarm söyleyen Kemal Satır ve arkadaşlarınındır. Bu müracaat üzerine, olağanüstü kurultayın, 20.Kurultay delegeleriyle, 5 Mayıs 1972 tarihinde Ankara'da toplanmasina lüzum görmekteyim.

Her iki tarafin gündemi birbirine yakındır. Gündem, bir cümle ile hülâsa olunabilir. Bu da, kurultayın Parti Meclisine güvenoyu verip vermeyeceği meselesidir. Bu kayıtlarla olağanüstü kurultayın toplanması için bütün ilgililerin yardımcı olmalarmı isterim." (Turan, 2004: 304-305).

CHP'nin 5 Mayıs 1972 tarihinde toplanması planlanan Beşinci Olağanüstü Kurultayı, İsmet İnönü'nün hafif bir kalp spazmı geçirmesi ve doktoru Zafer Paykoç'un kurultaya katılmasına sağlığı açısından izin vermemesi nedeniyle, 6 Mayıs 1972 tarihinde, Ankara Selim Sirrı Tarcan Spor Salonu'nda başlamıştır. (Tercüman, 6 Mayıs 1972) Kurultay, dinle- 
yicilere kapalı olarak, yalnızca basın mensupları ve izinli partili ve görevlilerin katılımıyla gerçekleşmiştir.

Genel Başkan İnönü, kurultayın açlış konuşmasında da eski Genel Sekreter Bülent Ecevit'i eleştirmiştir. İnönü'nün, Ecevit'i eleştirirken. CHP'nin orduyla olan ilişkilerine zarar verdiğine, hatta 27 Mayıs ve 12 Mart askerî müdahalelerine vurgu yapması dikkat çekicidir:

"Sayın Ecevit, sadece parti içi tutumu, davranışları dolayısıyla değil, ihtiyatsız şekilde ifade ettiği bir takım fikirlerden dolayı partinin dışında da şüpheler uyandırıyordu. Birçok defa bu ifadeleri 'Onun söylemek istediği budur' ya da 'bizim bu konudaki açık görüşümüz şöyledir' tarzında tavzih etmek mecburiyetini duyduğum herhalde gözünüzden kaçmamıştır ve hatırınıdadır. Sayın Ecevit'in bilhassa bu yüzden, resmî davetlerde ve ordu ile ilişkilerinde yanlış saydı$\breve{g}$ l tefsirlerden kurtulması için devaml bir dikkat göstermeye de çalıştım.

(...) Bugünkü durumumuz budur: Genel Başkanın parti teşkilâtını ve Meclis Gruplarını ahenk içinde çalışırmak gibi 40 yıldan beri tecrübe edilmiş bir vazife anlayışı tamamıyla hükümsüz bırakılmış, Meclis içinde ve dışında parti beraberliği, vatandaş gözünde değersiz ilân edilmiştir.

Genel Sekreterlikten istifa eden bir insanm, istifa etmemiş gibi parti idaresini yürütebilmesi, Parti Meclisindeki çokluk sayesinde mümkün olmaktadır.

Kanunlarn ve yetkilerin devlet yönetiminde iyi niyetten çıkarak kullanılmasl, toplumu büyük karışılığa ya da ihtilâle götürmüştür, götürecektir.

Tarihte, İttihad-ı Terakki Merkezi Umum İdaresi, Meclisleri vazifelerini göremez bir hale getirmişti. Demokrat Parti iktidar zamanında 'hiçbir kanun anayasaya aykırı olamaz' ilkesi şu şekilde işlenirdi: Bir kanunun anayasaya aykırı olup olmadığına Meclis karar verirdi. Onun için, anayasaya aykırı bir kanun göz göre göre çıkarllır ve şikâyet olursa, ertesi gün Meclis toplanır, çıkan kanunun anayasaya uygun olduğunu bildirirdi. Bu usul ile millet, anayasaya aykırı kanunlarla idare olunmaya başladı ve nihayet 27 Mayıs 1960 hareketi oldu.

12 Mart'tan önce yine böyle usullere uygun manzara altında bütün şikâyetleri üzerinde toplayan bir idare, 12 Mart'ı getirdi.

Bütün bu hâdiseler, demokratik rejimin geçirdiği tekâmül safhalarn sayılmalıdır. Ancak, bunların dersi de alınmalıdır." (Turan, 2004: 315-317). 
Kurultayın ikinci gününde ise İnönü'nün desteklediği Parti Meclisi listesiyle Ecevitçilerin Parti Meclisi listeleri güvenoyuna sunulmuştur. Aynı zamanda partide genel başkanlık için İnönü ile Ecevit arasında bir seçim anlamına gelen bu oylamayı, 507'ye karşı 709 oyla Ecevitçiler kazanmıştır. (Hürriyet, 8 Mayıs 1972) Bu sonuç, kurultay kararı alındığından beri "ya Bülent ya ben" diyen (Hürriyet, 25 Nisan 1972) İsmet İnönü'nün, CHP liderliğini kaybetmiş olduğu anlamına gelmektedir.

Kurultayda oy sayımı tamamlanıp sonuç açıklandıktan sonra eşiyle birlikte salondan ayrılan İnönü, ertesi gün, 8 Mayıs 1972 tarihinde CHP Merkez Yönetim Kurulu'na gönderdiği mektupla yaklaşık 34 yıldır sürdürmekte olduğu genel başkanlık görevinden istifa ettiğini bildirmiş ve parti tüzüğünün 28.maddesinin gerektirdiği işlemin yapılmasını talep etmiştir. (Hürriyet, 9 Mayıs 1972)

İnönü'nün istifa mektubunda vurguladığı, CHP Parti Tüzügünün 28.maddesi gereği, 14 Mayıs 1972 tarihinde, CHP'nin Genel Başkan Seçimi Kurultayı toplanmıştır. İnönü'nün Yalova'da istirahatte olduğu için katılmadığı kurultayda, tek aday olan CHP Zonguldak Milletvekili Bülent Ecevit, genel başkanlığa seçilerek, CHP'nin üçüncü genel başkanı olmuştur. (Cumhuriyet, 15 May1s 1972) Ecevit, 1416 delegeden 913'ünün katıldığı kongrede, 826 oy almıştır. Böylece, 12 Mart 1971 Askeri Müdahalesinin $\mathrm{CHP}^{\prime}$ de başlattığı bölünme, genel başkan değişikliğiyle sonuçlanmiştır.

\section{Cumhurbaşkanlığı Seçimi Krizi}

Ancak, 12 Mart Muhtırasının siyaset üzerindeki etkisi, bu kadarla sınırlı olmamıştır. CHP'deki değişiklikten 9 ay kadar sonra, mevcut Cumhurbaşkanı Cevdet Sunay'ın görev süresinin dolması ve yeni Cumhurbaşkanı'nın seçilmesinin gerekmesiyle, askerlerle sivil siyasiler arasında yeni bir kriz dönemi başlamıştır.

Krizin temel nedeniyse, 12 Martçlların, 28 Mart 1973 tarihinde görev süresi sona erecek Cumhurbaşkanı Cevdet Sunay'ın yerine, yine Sunay gibi Genelkurmay Başkanı olan Orgeneral Faruk Gürler'i Cumhurbaşkanı seçtirmek istemeleridir. Buna göre, Gürler Genelkurmay Başkanlığı 
görevinden istifa ederek kontenjan senatörü olacak ve kontenjan senatörlüğünden de Cumhurbaşkanlığı'na seçilecektir.

Orgeneral Faruk Gürler'in ismi, siyasî çevrelerde 1973'ün başlarından itibaren Cumhurbaşkanı adayı olarak konuşulmaya başlamakla birlikte, basında kesin ifadelerle Şubat ayı sonları ve Mart ayının başlarında yer almaya başlamıştır. Cumhuriyet Gazetesi'nde 2 Mart 1973 tarihinde yayımlanan bir yazıda, "bir üye istifa edecek, Sayın Gürler Cumhuriyet Senatosu'na girecek ve Cumhurbaşkan olarak Çankaya'ya gidecek" ifadeleriyle, yukarıdaki formüle vurgu yapılmıştır. (Cumhuriyet, 2 Mart 1973)

Parlamentoda, mevcut Genelkurmay Başkanı'nın Cumhurbaşkanı olarak seçilmesine en erken ve belirgin tepkiyi gösteren liderse, Adalet Partisi Genel Başkanı Süleyman Demirel olmuştur. 12 Mart Muhtırası ile hükümetten uzaklaştırılan Demirel, Gürler'in Cumhurbaşkanı olmasına karşı olduğunu, 1973 başlarından itibaren basına verdiği röportajlarla açıklamıştır. Demirel, sürekli olarak “Cumhurbaşkanı'nı TBMM'nin seçeceği" vurgusunu yaparak, Meclis dışından bir adaya sıcak bakmadığ1nı, dolaylı olarak da Gürler'i desteklemeyeceğini ifade etmiştir. (Son Havadis, 5 Şubat 1973; Cumhuriyet, 2 Mart 1973).

CHP'nin tavrıysa, Faruk Gürler' in adı kesinleşene kadar net değildir. Ancak Ecevit de, Demirel gibi, askerler tarafından Gürler'in adaylığının dayatılmasından kaygılı ve Gürler'in adaylığına mesafelidir. CHP Genel Başkanı Ecevit, o günlerdeki atmosferi özetle şöyle anlatmaktadır:

"Cumhurbaşkanı seçimiyle ilgili olarak bir baskının ortaya çıkmasından çok kaygı duyuyorduk. Öyle bir baskı olduğu takdirde ona karşı direnmemiz gerektiğinde hepimiz birleşiyorduk. Öyle bir huzursuz bekleyiş içindeyken ve türlü söylentiler devam ederken sayın Muhsin Batur'un² evine bir çağrı aldım. Yanlış hatırlamıyorsam, çă̆rıyı Muhsin Batur yaptı. Benimle, istediğim yakın arkadaşlarımla bir özel görüşme ihtiyacı duydukların belirtti.

(...) Birlikte gideceğimiz arkadaşlarla toplandık. Genel sekreter ve grup başkan vekilleriyle birlikte gidecektik. Gitmeden önce bizim evde toplandık ve Gürler'in adaylığının desteklenmesi yolunda bir telkin ve ya bask gelecek olursa, buna karşı gönül kırmayıcı bir uslûp içinde yardımcı olamayacağımızı belirtmek kararı aldık.

\footnotetext{
${ }^{2}$ Orgeneral Muhsin Batur, dönemin Genelkurmay 2.Başkanı'dır.
} 
Toplantı çok nazik ve dikkatli bir hava içinde geçti. Ve kesinlikle Gürler'in adaylı̆̆ $ı$ konusunda bir telkinde bulunmadılar. Ancak bir-iki kumandanın konuşmalarından, bizde öyle bir eğilim olursa memnun olunabileceği gibi bir hava seziliyordu. Daha çok, bizim Demirel'le bir araya gelip bu soruna bir çz̈züm bulmamızın, iki büyük partinin, ordunun duyarlığın ve sorunların göz önünde tutarak uygun bir aday üzerinde görüş birliğine varmasının kendilerini rahatlatacağın bize belli ettiler.

Anlaşılan, böyle bir girişim için Demirel'i kapalı buluyorlardı. Ertesi gün benim bu görüşmeyi Demirel'le yapmamı kararlaştırdık. Demirel benimle görüşmekten ısrarla kaçındl. Ben bu görüşmeye çok önem veriyordum. Çünkü bunu yapmazsak Gürler'in adaylığının ortaya sürülmesi gibi bir durumla karşılaşılacaktı." (Kili, 1976:342-343)

Bu görüşme ve gelişmelerin sonunda, siyasî liderlerin kesin bir aday bildirmemelerinin de sonucu olarak, askerlerin Orgeneral Faruk Gürler üzerindeki tavrı kesinleşmiştir. Millî Savunma Bakanı Mehmet İzmen, yerine Faruk Gürler'in geçmesi için 5 Mart 1973 tarihinde kontenjan senatörlüğünden istifa etmiştir (Cumhuriyet, 6 Mart 1973). Ertesi gün de Gürler emekliliğini istemiş, 7 Mart 1973 tarihinde de yemin ederek Cumhurbaşkanlığı adaylığının ilk adımı olan senatörlük görevine başlamıştır. (Cumhuriyet Senatosu Tutanak Dergisi, Cilt 10, 7 Mart 1973: 201) Gürler'den boşalan Genelkurmay Başkanlığı makamınaysa Kara Kuvvetleri Komutanı Orgeneral Semih Sancar atanmıştır.

Gürler'in Cumhurbaşkanlığı adaylığının bu şekilde kesinleştiği günlerde de siyasî parti liderlerinin tavrında bir değişiklik yoktur. Demirel, Cumhurbaşkanı'nı TBMM'nin seçeceği konusundaki vurgusuna devam etmektedir. Demirel'e göre bu vurgu "bir şeyleri saklamak için söylenmiş süslü bir söz değildir." (Cumhuriyet, 6 Mart 1973) Ecevit'in açılamaları da öncekilere benzerdir. Gürler'in Genelkurmay Başkanlığ1 görevinden istifa ettiği gün yaptığı açıklamada, “CHP'nin kesin bir kararının olmadığı$n \imath^{\prime \prime}$ ifade etmiştir. (Cumhuriyet, 7 Mart 1973)

TBMM'de Cumhurbaşkanlığ1 için seçim turlarının başlayacağ1 13 Mart 1973 gününe kısa süre kala, Adalet Partisi, Cumhurbaşkanı seçilmesinden çok Gürler'in önünü kesmesi amaciyla Cumhuriyet Senatosu Başkanı Emekli Orgeneral Tekin Arıburun'u, Demokratik Parti ise diğer 
iki adaya da oy vermemek için Genel Başkanı Ferruh Bozbeyli'yi aday göstermiştir. CHP'ninse halen bir adayı yoktur. Ecevit, CHP'nin seçim turlarına katılmamasını önermiş, karar kabul edilmesine karşın Genel Sekreter Kırıkoğlu ve 30 kadar CHP'li, Ecevit'in talimatı ve grup karar1na karşı çıkarak seçim turlarına katılmıştır. (Kili, 1976:343-344)

13 Mart 1973 tarihli TBMM Birleşik Toplantısıyla başlayan Cumhurbaşkanlığı seçiminin ilk turunda, AP'nin adayı Tekin Arıburun 282, askerlerin desteklediği Faruk Gürler 175, Demokratik Parti'nin adayı Ferruh Bozbeyli ise 45 oy almıştır. 11 oyun boş, 4 oyunsa geçersiz sayıldığ 1 turda, 2/3 oy çokluğu sağlanamadığından Cumhurbaşkanı seçilememiştir. (TBMM Tutanak Dergisi, Cilt 12, 13 Mart 1973: 147)

Sonraki dört turda da benzer şekilde çoğunluk sağlanamayıp Cumhurbaşkanlığı seçimi çıkmaza girmeye başlayınca, sonucun değişmeyeceğini anlayan Faruk Gürler, adaylıktan çekildiğini açıklamıştır. Gürler'le birlikte, AP'nin desteklediği Tekin Arıburun da adaylıktan çekilmiştir. Artık oylama turlarına katılmayan AP ve CHP'nin, ortak olarak destekleyecekleri bir adaylarının da olmaması nedeniyle, Cumhurbaşkanlığı seçim süreci tıkanmıştır. Bu aşamada, CHP Lideri Bülent Ecevit'in 1 hafta kadar önce, 16 Mart 1973 günü gündeme getirdiği ve CHP Parti Meclisi'nden de yetki aldığı çözüm önerisi olan, mevcut Cumhurbaşkanı Cevdet Sunay'ın görev süresini uzatılması önerisi tekrar değerlendirilmiştir.

CHP'nin, anayasada değişiklik yapılarak Cumhurbaşkanı'nın görev süresinin uzatılması teklifi, 303 milletvekilinin imzasıyla 22 Mart 1973 günü Millet Meclisi gündemine alınmıştır. Değişiklik Meclis'te tartışılmış, aynı gün oylanmış, fakat $2 / 3$ çoğunluğun gerektirdiği 300 oydan yalnızca 1 oy eksikle, 299 oyla reddedilmiştir. Değişikliği teklif eden CHP'nin, Uşak Milletvekili Adil Turan, teklife karşı oy kullanmıştır. (Millet Meclisi Tutanak Dergisi, Dönem 3, Cilt 36, 22 Mart 1973: 342-345)

Tasarı, Millet Meclisi'nde reddedilmiş olmasına karşın, Cumhuriyet Senatosu'na da gönderilmiş, burada da tartışılarak oylanmış, ancak 104 kabul oyu almasına karşın, 184 üyeli Senato'da da 2/3 çoğunluğu elde edemediğinden reddedilmiştir. (Cumhuriyet Senatosu Tutanak Dergisi, Cilt 10, Toplantı 12, 25 Mart 1973: 456-458)

Gürler adaylıktan çekilip Sunay'ın görev süresi de uzatılamayınca, siyasî parti liderleri, daha fazla vakit kaybetmeden yeni bir aday belirle- 
mek için görüşmelere başlamışlardır. 26 Mart 1973 günü, dönemin Anayasa Mahkemesi Başkanı Muhittin Taylan, partilerin ortak adayı olarak belirlenmiştir. Ancak, bu kez de Cumhurbaşkanı Cevdet Sunay, kontenjan senatörlüğü mekanizmasını Taylan için işletmeyi reddetmiştir. (Cumhuriyet, 27 Mart 1973; Kili, 1976: 346)

Bunun üzerine, kısa süre ara verilen görüşmeler Nisan ayının başında yeniden başlamış, AP Lideri Demirel, çözüm olarak Cumhurbaşkanı'nı halkın seçmesini önermiştir. (Cumhuriyet, 3 Nisan 1973) Ancak bu öneri de diğer liderler tarafından kabul görmemiştir. Sonunda, Demirel ve Ecevit ikili olarak görüşmüş ve Kontenjan Senatörü Emekli Oramiral Fahri Korutürk üzerinde uzlaşmışlardır.

Korutürk'ün aday olduğu Cumhurbaşkanlığı seçimi, 6 Nisan 1973 tarihinde, TBMM Birleşik Oturumunda yapılmıştır. Aynı zamanda Cumhurbaşkanlığ seçiminin 15.turu olan bu oylamada, 365 oy alan Fahri Korutürk Cumhurbaşkanlığına seçilmiştir. Korutürk, aynı gün Meclis'te yemin ederek, Türkiye Cumhuriyeti'nin altıncı Cumhurbaşkanı olarak göreve başlamıştır. (TBMM Tutanak Dergisi, Cilt 12, Toplantı 12, 6 Nisan 1973: 224-225)

Böylece, 12 Mart Muhtırasından kısa süre sonra, henüz muhtıracıların kurdurduğu hükümetlerin ara rejimi devam ederken, askerler ile sivil siyaset arasında yaşanan ve yaklaşık 1 ay kadar süren bu otorite mücadelesi, sivil siyasetin desteklediği bir adayın Cumhurbaşkanı olmasıyla son bulmuştur. Altıncı Cumhurbaşkanlığı seçimi, asker-sivil ilişkileri açısından Cumhuriyet tarihimizdeki örnek olaylardan biri olarak kabul edilmektedir.

\section{1973 Genel Seçimleri, Sivil-Seçilmiş Hükümetin Kurulması ve Ara Rejimin Sonu}

Cumhurbaşkanlığ krizinin de bu şekilde aşılmasından sonra, zamanı gelen genel seçimlerin normal tarihinde yapılmasına karar verilmiştir.

CHP, bu seçimlere önem vermiş ve 1969 seçimlerinden itibaren ülkenin yaşadığı sıkıntıları vurgulayan 234 sayfalık "Ak Günlere" başlıklı iddialı bir kitapçı ve seçim bildirgesi hazırlamıştır. CHP'nin bu bildirgede yoğunlaştığı konular, 12 Mart Askeri Müdahalesinin siyaset ve 
ekonomiye olumsuz etkileri, özgürlüklerin kısıtlanması, demokrasinin gördüğü zarar ve asayiş sorunlarıdır. (Ak Günlere: CHP 1973 Seçim Bildirgesi, 1973) CHP, bu seçimlerle birlikte, "sürekli bir anamuhalefet partisi olmaktan kurtulmayı" amaçlamaktadır.(Kili, 1976: 349)

AP de, seçim çalışmalarında demokrasi vurgusuna önem vermiştir. Öyle ki, partinin seçim çalışmaları için belirlediği ve seçim propaganda çalışmalarında en sık kullandığ 1 sloganlardan biri "demokrasinin bayrağ1 $\mathrm{AP}^{\prime \prime}$ sloganı olmuştur. (Cumhuriyet, 11 Eylül 1973)

Seçimlere katılacak diğer partiler arasında ise Mart'ta yaptığı kongreyle adını değiştiren (Tercüman, 5 Mart 1973) Turhan Feyzioğlu liderliğindeki Cumhuriyetçi Güven Partisi (CGP), 12 Mart Muhtırasından sonra kapatılan Milli Nizam Partisi'nin yerine 11 Ekim 1972 tarihinde yine Necmettin Erbakan liderliğinde kurulan (Günaydın, 12 Ekim 1972) Milli Selamet Partisi (MSP), Alparslan Türkeş liderliğindeki Milliyetçi Hareket Partisi (MHP) ve Ferruh Bozbeyli liderliğindeki Demokratik Parti (DP) yer almıştır.

Toplam 8 partinin katıldığı 1973 Genel Seçimleri, 14 Ekim günü yapılmıştır. 16 milyon 798 bin 164 kayıtlı seçmenden 11 milyon 223 bin 843'ünün oy kullandığ1 ve \%66.8 katılım oranıyla gerçekleşen seçimlerin kazananı ise Bülent Ecevit'in liderliğindeki CHP olmuştur. 3 buçuk milyondan fazla oy ve \%33.3 oy oraniyla 185 milletvekilliği kazanan CHP'yi, \%29.8 oy oranı ve 149 milletvekiliyle Süleyman Demirel'in AP'si izlemiştir. MSP 48, DP 45, CGP 13, MHP ise 3 milletvekilliği kazanmıştır. (TÜİK, 2012: 25) Basında yer alan pek çok değerlendirmeye göre, CHP'nin İstanbul, Ankara, İzmir gibi şehirlerde $\mathrm{AP}^{\prime}$ yi geride bırakarak seçimi kazanmış olması bir sürprizdir. Bu sürprizin temel nedenlerinden biri de, DP ve MSP'nin, AP'nin oylarını bölmüş olmasıdır. (Hürriyet, 15 Ekim 1973)

Seçimlerin sonuçlanmasıyla birlikte, Cumhurbaşkanı Fahri Korutürk, hükümeti kurma görevini CHP Lideri Bülent Ecevit'e vermiştir. Aldığ oy tek başına hükümet kurmaya yetmeyen Ecevit, koalisyon için ortak bulmak zorundadır. AP Lideri Demirel, "halkın kendilerine muhalefet görevini verdiği" gerekçesiyle hiçbir partiyle koalisyon kurmayacağını açılamıştır. Zaten CHP içerisinde de AP ile koalisyon kurmak istemeyen irade çoğunluktadır. Bunun üzerine Ecevit'in koalisyon görüşmeleri, Necmettin Erbakan'in MSP'siyle yoğunlaşmıştır. 
Yukarıdaki nedenler dışında, CHP'yi MSP ile koalisyon hükümeti kurmaya iten bir diğer neden de, ideolojik ve dünya görüşü farklarına karşın, iki partinin ekonomik ve toplumsal sorunlara yaklaşım tarzının benzerliğinin, iki partinin de bu sorunlara ağırlık vermesinin etkisidir. Ayrıca, seçim kampanyaları boyunca her iki parti de temel rakip olarak AP'yi görmüş ve birbirlerine karşı sert bir mücadele yürütmemiş, halkın sorunları, özlemleri üzerinde durarak bunlara yönelik çözümler üzerinde durmuştur. İki parti arasındaki diğer bir yakınlaşma nedeniyse, düşünce özgürlüğü konusu olmuştur. CHP, 1973 seçimlerinde 12 Mart'a yol açan ortamın ve 12 Mart sonrası dönemin cezaevlerine sürüklediği sanık ve suçluları kurtarmak, bir "iç barış" sağlamak amacıyla genel af çıkaracağını taahhüt etmiştir. MSP de, CHP'den farklı nedenlerle de olsa, geniş kapsamlı bir af çıkarılmasını istemiştir. Bu da, zaten başka koalisyon ortağı bulamayan Ecevit için bir yakınlaşma nedeni olmuştur. (Kili, 1976: 372-373)

Ecevit'in hükümet kurma çalışmaları yaklaşık 2 ay sürmüş, bu süre içerisinde hükümet kurma görevini bir kez Cumhurbaşkanı'na iade etmiş, Demirel de hükümet kuramayınca görevi tekrar almıştır. Bu uzun ve zor süreçten sonra, CHP ile MSP, koalisyon hükümeti konusunda anlaşmış, bakanlıklar paylaşılmış ve protokol imzalanmıştır. (Milliyet, 26 Ocak 1974) Bülent Ecevit'in Başbakan, Necmettin Erbakan'ın ise Başbakan Yardımcısı olduğu 25 bakanlı hükümette, 18 bakanlık CHP'den, 7 bakanlıksa MSP'den seçilmiştir. Kabinede, 23 vekille birlikte 2 de senatör yer almıştır. (Neziroğlu-Yılmaz, 2015: 578-591)

Hükümet listesinin Cumhurbaşkanı Korutürk tarafından onaylanmasının ardından, hükümet programı 1 Şubat 1974'de Millet Meclisi ve Cumhuriyet Senatosu'nda okunarak görüşülmüş ve onaylanmıştır. (MM Tutanak Dergisi, Dönem 4, Cilt 1, 1 Şubat 1974: 349-364; Cumhuriyet Senatosu Tutanak Dergisi, Cilt 13, 1 Şubat 1974: 352-367)

Hükümet programinda genel olarak;

- Siyasi hakların iadesi,

- Genel af,

- İmam-Hatip Okullarının yeniden açılması,

- Yükseköğretimin parasız ve üniversiteye girişin sınavsız olması,

- Vergi sisteminde iyileştirmeler yapılması, 
- Tarım kredilerinin artırılması,

- Sanayi ve kooperatifçiliğin geliştirilmesi,

- Gecekondulara tapu verilmesi, yasallaştırılması,

- Nüfusun orantılı dağılımı için "Köy-kent" ve uydu kentlerin kurulması gibi konu başlıkları yer almıştır. (Milliyet, 2 Şubat 1974)

12 Martçıların kurdurduğu 4 hükümetten sonra, genel seçimle halkın seçtiği bir hükümetin yeniden göreve gelmesiyle, üç yıl kadar süren 12 Mart ara rejimi son bulmuştur.

\section{Sonuç}

12 Mart 1971'de gerçekleşen askerî müdahale, yalnızca müdahalenin hedefindeki Demirel'in Adalet Partisi'ni değil, Türkiye'nin önemli siyasî aktörlerinin çoğunu etkilemiştir. Askerî müdahaleden sonra 1974 yılına kadar devam eden ara rejim süreci, bu etkilerin belirgin olarak gözlemlenebildiği bir dönem olarak karşımıza çıkmaktadır.

Bu bağlamda, muhtıra, iktidardan uzaklaştırılan AP ile birlikte, anamuhalefet partisi olan CHP'yi de etkilemiştir. Muhtırayı olumlu karşılayan ve muhtıracıların kuracağı hükümete bakan vermeyi kabul eden CHP Genel Başkanı İsmet İnönü ile muhtıraya açıcça tepki gösteren Genel Sekreter Bülent Ecevit arasında görüş ayrılığı ortaya çıkmış ve bu ayrılık kısa süre içerisinde partide bir bölünmeye neden olmuştur. İnönü'ye tepki olarak genel sekreterlik görevinden istifa eden Ecevit, bir süre sonra genel başkanlık için İnönü'nün rakibi olmuş ve sonunda, 1972 yılının Mayıs ayında gerçekleşen CHP Beşinci Olağanüstü Kurultayı'nda İnönü'ye üstünlük sağlayarak partinin genel başkanı olmuştur. Böylece, 12 Mart Askerî Müdahalesi, dolaylı olarak, CHP’nin 34 yıllık genel başkanı İnönü'nün görevinden ayrılması gibi çarpıcı bir gelişmeye neden olmuştur.

Muhtıranın diğer bir etkisiyse, 1973 yılında yapılan Cumhurbaşkanl1ğ1 seçimleri üzerinde meydana gelmiştir. Genelkurmay Başkanı Faruk Gürler'i Cumhurbaşkanı seçtirmek isteyen askerlerle, buna karşı olan sivil siyasî liderler arasında bu kez de bir Cumhurbaşkanlığı krizi patlak vermiş̧ir. Kriz, ülkenin en çok vekile sahip iki partisi olan AP ve CHP'nin liderleri Süleyman Demirel ve Bülent Ecevit'in ortak hareket 
ederek, Faruk Gürler'e karşı emekli Oramiral Fahri Korutürk'ü Cumhurbaşkanı seçmeleriyle, sivil siyasilerin istediği şekilde sonuçlanmıştır.

Yaklaşık 3 buçuk yıl kadar süren ve askerlerin kurdurduğu dört hükümetle yönetilen ara rejim, 14 Ekim 1973 tarihinde yapılan genel seçimler sonucu en yüksek oyu alan CHP Lideri Bülent Ecevit'in, MSP Lideri Necmettin Erbakan'la anlaşarak koalisyon hükümeti kurması ve Şubat 1974'de göreve başlamasıyla sona ermiştir. 
EXTENDED ABSTRACT

\title{
Interim Regime After March 12, 1971 Military Inter- vention and the Effects to the Turkish Politics (1971- 1974)
}

\author{
$*$ \\ Barış Ertem \\ Istanbul Technical University
}

The first direct intervention of the soldiers in politics in Turkey, took place on May 27, 1960. This military intervention was made against Prime Minister Adnan Menderes and his Democratic Party (DP) Government. Prime Minister Adnan Menderes was removed from power and executed. One of the founders of the Democratic Party, Presindent of the Republic of Turkey, Celal Bayar was also removed from his presidency. The leader of the coup d'état, General Cemal Gürsel was appointed to the presidency. Constitution changed by coup regime. A new junta-supported government established. The leader of this new government and new Prime Minister was İsmet İnönü. Four years later, general elections were held again in the year of 1965 . A young politician, Süleyman Demirel and his Justice Party, won the election. Leader of the May 27, 1960 coup and President of the Turkish Republic, General Cemal Gürsel approved the Süleyman Demirel's government. The Justice Party Government won a vote of confidence from Grand National Assembly of Turkey on November 11, 1965. And Süleyman Demirel began his duty as new Prime Minister of the Republic of Turkey. Demirel will continue this duty until nother military coup d'état, March 12, 1971. In the late 1960's, anti-Americanism and leftist movements increased in Turkey. The main reason for this was the US's pro-Greek position on Cyprus. US did not allow Turkey to intervene in Cyprus. US also did not give much confidence in Turkey against the Soviet Union in the Cold War. Political struggle and violence began in the country. Mass strikes organized by 
trade unions. Violence spread to universities. There were clashes among university students. The Demirel Government was also having problems in diplomacy. US President Richard Nixon, asked for the ban on opium cultivation in Turkey. Prime Minister Demirel refuses Nixon's request. A new diplomatic crisis between the US and Turkey occurred. The pressure on the Demirel Government of the USA has been continuously increased.

On March 12, 1971, Prime Minister of Republic of Turkey, Süleyman Demirel was given a memorandum by the soldiers. This memorandum was soldiers' second direct intervention to the civilian and selected political power in the history of the Republic of Turkey. As a result of this military intervention, ruling Prime Minister Süleyman Demirel and his Justice Party Government (AP) fell from power. Impact of the military intervention on Turkish politics was about three and a half years.

In this three and a half years, four governments served:

Nihat Erim Government (March 26, 1971-Decemler 11, 1971)

Nihat Erim Government (December 11, 1971-May 22, 1972)

Ferit Melen Government (May 22, 1972-April 15, 1973)

Mehmet Naim Talu Government (April 15, 1973-January 26, 1974)

In this process, a party leader exchange occured in The Republican People's Party (CHP). İsmet İnönü, the 34-year-old Chairman of the Republican People's Party and second president of the Republic of Turkey, lost his place in the party. İsmet İnönü has supported the memorandum. But Bülent Ecevit, General Secretary of the Republican Proples Party, has came against the memorandum and resigned from his duty. İsmet İnönü and Bülent Ecevit faced for leadership of the Republican People's Party. Eventually, former general secretary, Bülent Ecevit, became the new Chairman of the Republican People's Party. Bulent Ecevit will remain as head of the CHP, until another military intervention, September 12, 1980 military coup. The March 12, 1971 military memorandum also affected the presidential elections held in year of 1973. The soldiers and civilian politicians have faced about presidential candidate. Fahri Korutürk, supported candidate by Süleyman Demirel and Bülent Ecevit, elected as president. General Faruk Gürler, supported candidate by soldiers, has lost the elections. The general elections also held in October, 1973. Re- 
publican People's Party (CHP), led by Bülent Ecevit, has won the elections. But he had to set up a coalition government. Ecevit did not want to set up a coalition government with Süleyman Demirel and his Justice Party. Ecevit has formed a coalition government with Necmettin Erbakan-led National Salvation Party (MSP). President Fahri Korutürk has approved the Republican People's Party-National Salvation Party (CHPMSP) Coalition Government. On February 1, 1974, new coalition government received a vote of confidence from The Grand National Assembly of Turkey (TBMM). Republican People's Party leader Bulent Ecevit started his duties of the Prime Minister. And the National Salvation Party leader Necmettin Erbakan became the Deputy Prime Minister. As the result of formation of this civilian coalition government, the interim regime has ended. This civil governments period lasted about six and a half years. And a new military coup took place in Turkey on September 12,1980

\section{Kaynakça / References}

Ak Günlere: CHP 1973 Seçim Bildirgesi, Yayın yeri belirsiz, 1973

Cumhuriyet Senatosu Tutanak Dergisi, Cilt 10, Toplantı 12, 7 Mart 1973

Cumhuriyet, 11 Eylül 1973

Cumhuriyet, 13 Mart 1971

Cumhuriyet, 15 Mayıs 1972

Cumhuriyet, 17 Nisan 1972

Cumhuriyet, 2 Mart 1973

Cumhuriyet, 2 Mart 1973

Cumhuriyet, 27 Mart 1973

Cumhuriyet, 3 Nisan 1973

Cumhuriyet, 6 Mart 1973

Cumhuriyet, 6 Mart 1973

Cumhuriyet, 7 Mart 1973

Ertem, B. (2014), “Türkiye Cumhuriyeti Tarihinde Asker-Sivil İlişkileri (19232000), Modern Türkiye Tarihi, (ed.Ali Satan, Süleyman Beyoğlu), İstanbul: Marmara Üniversitesi Yayınları, s.423-440 
Ertem, B. (2016). Türk siyasetinde asker-sivil ilişkileri (1960-1971). Dicle Üniversitesi Sosyal Bilimler Enstitüsü Dergisi, 8(16), 132-149

Günaydın, 12 Ekim 1972

Hürriyet, 15 Ekim 1973

Hürriyet, 22 Mart 1971

Hürriyet, 25 Nisan 1972

Hürriyet, 8 Mayıs 1972

Hürriyet, 9 Mayıs 1972

Kili, S. (1976). 1960-1975 Döneminde Cumhuriyet Halk Partisi'nde Gelişmeler: Siyaset Bilimi Açısından Bir İnceleme. İstanbul: Boğaziçi Üniversitesi Yayınları.

Millet Meclisi Tutanak Dergisi, Dönem 3, Cilt 36, 22 Mart 1973

Millet Meclisi Tutanak Dergisi, Dönem 4, Cilt 1, 1 Şubat 1974; Cumhuriyet Senatosu Tutanak Dergisi, Cilt 13, 1 Şubat 1974

Milletvekilli Genel Seçimleri: 1923-2011, (2012), Türkiye İstatistik Kurumu (TÜİK), Yayın no.3685, Ankara

Milliyet, 13 Mart 1971

Milliyet, 2 Şubat 1974

Milliyet, 26 Ocak 1974

Mirkelamoğlu, N. (1975). İnönü Ecevit'i Anlatıyor, Kervan, İstanbul

Neziroğlu, İ. ve Yılmaz, T. (2015), Koalisyon Hükümetleri, Koalisyon Protokolleri, Hükümet Programları ve Genel Kurul Görüşmeleri, TBMM, Ankara

Son Havadis, 5 Şubat 1973

TBMM Tutanak Dergisi, Cilt 12, Toplantı 12, 13 Mart 1973

TBMM Tutanak Dergisi, Cilt 12, Toplantı 12, 6 Nisan 1973

\section{Kaynakça Bilgisi / Citation Information}

Ertem, B. (2018). 12 Mart 1971 askerî müdahalesi sonrası ara rejim ve Türkiye siyasetine etkileri (1971-1974). OPUS - Uluslararası Toplum Araştırmaları Dergisi, 8(14), 655-676. DOI: 10.26466/opus.407560 